\title{
Upper Kellwasser Carbon Isotope Excursion Pre-Dates the F-F Boundary in the Upper Devonian Lennard Shelf Carbonate System, Canning Basin, Western
}

Australia

Kelly Hillbun ${ }^{1}$, Ted E. Playton ${ }^{2}$, Eric Tohver ${ }^{3}$, Ken Ratcliffe ${ }^{4}$, Kate Trinajstic ${ }^{5}$, Brett Roelofs ${ }^{5}$, Samuel Caulfield-Kerney ${ }^{6}$, David Wray ${ }^{6}$, Peter Haines ${ }^{7}$, Roger Hocking ${ }^{7}$, David Katz ${ }^{8}$, Paul Montgomery ${ }^{9}$, and Peter Ward ${ }^{1}$

${ }^{1}$ University of Washington, ESS Dept. Box 351310, 4000 15th Avenue N.E., Seattle, WA, 98195. khillbun@uw.edu, 1-650-274-9832

${ }^{2}$ Chevron Energy Technology Company, Houston, TX, USA

${ }^{3}$ University of Western Australia, Perth, Western Australia

${ }^{4}$ Chemostrat Ltd., Welshpool Powys, UK

${ }^{5}$ Curtin University, Perth, Western Australia

${ }^{6}$ University of Greenwich, London, UK

${ }^{7}$ Geological Survey of Western Australia, East Perth, Western Australia

${ }^{8}$ Whiting Petroleum Corporation

${ }^{9}$ Chevron Energy Technology Company, Aberdeen, UK

\section{ABSTRACT}

Here we report four high-resolution carbon isotope records in addition to trace element data for the Frasnian-Famennian (F-F) boundary interval in the Lennard Shelf carbonate system of the Canning Basin, Western Australia. This region lacks the characteristic black shale horizons associated with the global Late Devonian Kellwasser extinction events, yet still exhibits a trend in carbon isotope character similar to what has been reported from elsewhere in the world (two positive $\delta^{13} \mathrm{C}$ excursions with $\sim 3-4 \%$ amplitudes). Enrichments in select trace element ratios suggest that both excursions are related to periods of oxygen deprivation and perhaps increased biological productivity. Given the continuous and stratigraphically expanded nature of Lennard Shelf sections, together with high density sampling constrained by both conodont 
biostratigraphy and magnetostratigraphy, we observe that the Upper Kellwasser isotope excursion (maximum $\delta^{13} \mathrm{C}$ values) and associated trace element enrichments occur distinctly lower than the F-F boundary level. These results have implications for the paleoenvironmental conditions leading up to the Late Devonian Mass Extinction in terms of ocean chemistry and circulation patterns. This dataset allows for a rare, detailed look at the temporal relationship between the Kellwasser events and the F-F boundary and constrains the pattern of carbon isotope perturbations at the intra-zonal scale.

KEY WORDS: Kellwasser; Upper Devonian; F-F boundary; carbon isotopes; Lennard Shelf carbonate system, Canning Basin

\section{INTRODUCTION}

The Late Devonian Mass Extinction (LDME) is recognized as one the five greatest biotic crises of the Phanerozoic (Sepkoski, 1986). Decades of research on numerous European localities has led to the understanding that there are actually two separate extinction pulses known as the Upper and Lower Kellwasser events in the linguiformis (or Montagne Noire Zones 13b and 13c of Klapper, 1989) and rhenana (Montagne Noire Zones 12 and 13a) conodont Zones, respectively, of the late Frasnian. These horizons are characterized by significant faunal turnover, positive carbon isotope excursions (average amplitude of about $+3 \%$ ), and the deposition of black shales and bituminous limestones (e.g. McGhee, 1996), and are thought to reflect widespread anoxic conditions (Feist, 1985; Buggisch, 1991; Wendt and Belka, 1991; Hallam and Wignall, 1999) during pulses of sea level transgression (Johnson et al., 1985; Sandberg et al., 1988; Buggisch, 1991; Sandberg et al., 2002). 
However, the timing of the carbon isotope excursion associated with the Upper Kellwasser deposits and extinctions in Europe (herein referred to as the Upper Kellwasser excursion) is not well constrained and the cause(s) poorly understood. The majority of Late Devonian geochemical studies document Upper Kellwasser excursion maxima at or slightly higher than the F-F boundary (e.g. Joachimski et al., 2002; Xu et al., 2003; Buggisch and Joachimski, 2006; George et al., 2014). As a result, they inadvertently lump the succession of related geo- and bioevents together and give the illusion that the Upper Kellwasser excursion and F-F boundary are time-equivalent. This can be particularly problematic when attempting to make chronostratigraphic correlations or to determine causal mechanisms.

Exacerbating these problems are the conflicting isotope records that have been reported for this time period, with some workers noting either the absence of isotopic excursions (Geldsetzer et al., 1987), or the occurrence of negative excursions (Wang et al., 1991;Goodfellow et al., 1988), or the absence of organic-rich deposits (e.g. Joachimski and Buggisch, 1993; Bond et al., 2004). These discrepancies have generated debate over the role of global anoxia as a potential kill mechanism. Paleo-redox data for this time interval are also contradictory: whereas the trace element analyses from most studies have given credence to oceanic anoxia (e.g. Riquier et al., 2006), others infer oxic conditions (e.g. George et al., 2014). Furthermore, in many localities around the world, F-F boundary sections are highly condensed (e.g. Joachimski et al., 2002), or incomplete due to unconformities and depositional hiatuses related to the sharp marine regression in the uppermost Frasnian (Johnson et al., 1985; Sandberg et al., 1988; Geldsetzer et al., 1993; Muchez et al., 1996; Stephens and Sumner, 
2003), and/or limited in terms of sampling density or biostratigraphic control at the intra-

biozonal scale (e.g. Bratton et al., 1999; Stephens and Sumner, 2003; van Geldern et al., 2006).

This contribution reports new data from the northern margin of Gondwana in order to constrain the timing of the Upper Kellwasser excursion and to better understand the causal mechanism(s) relating to the Kellwasser events. Here we present four detailed carbon-isotope profiles, constrained at the intra-zonal level by high-resolution conodont biostratigraphy and magnetostratigraphy. We obtained our data from measured outcrop sections through organicpoor facies in variable slope environments of the Lennard Shelf mixed carbonate-siliciclastic system, Canning Basin, Western Australia (Figure 1). In this region, middle-slope brecciagrainstone and upper-slope boundstone settings appear to be stratigraphically expanded relative to many other global localities. In Europe, for example, Conodont Zone 13 (Figure 2) is generally $<2$ m-thick (Buggisch and Joachimski, 2006), whereas in this study the same interval of time is represented by $>20$ m of stratigraphy. As such, our sections provide a continuous, more expanded view of upper Frasnian to lower Famennian strata and allow for a more detailed examination of the Upper Kellwasser excursion as it relates to the timing of the F-F boundary. The stable isotope data, with some accompanying trace element analyses, also provide insight into changes in the global carbon pool and redox conditions of the ocean during this time.

\section{AREA DESCRIPTIONS, METHODS \& MATERIALS STUDIED}

During the Middle Devonian, subsidence and rifting of the Canning Basin (e.g. Veevers and Wells, 1961; Kennard et al., 1994) led to the prolific growth of carbonate reefs along the shallow terraces of the Lennard Shelf. Today, over $350 \mathrm{~km}$ of Middle to Late Devonian 
carbonates are exposed in the northern part of the basin and have been subjected to decades of stratigraphic, paleontological, and geochemical research (Guppy et al., 1958b; Playford and Lowry, 1966; Druce, 1976; Playford, 1980; Becker and House, 1997; George et al., 1997;

Stephens and Sumner, 2003; Nothdurft et al., 2004; Playford et al., 2009; and others). During the interval of time most relevant to this study, namely the Late Frasnian and Early Famennian, the reefal platform and slope system exhibited progradational growth morphology and experienced episodic collapse events that transported large amounts of material down-slope (Playford, 1980; Sandberg et al., 2002; Playton, 2008; Playford et al., 2009). An abrupt fall in sea level coincident with the F-F boundary resulted in the sub-aerial exposure and erosion of platform-top facies while sedimentation continued uninterrupted on the slope and in the basin. As such, deeper water settings were preferentially targeted in this study because of their potential for stratigraphic completeness.

Four stratigraphic sections from sites spanning $200 \mathrm{~km}$ across the Lennard Shelf outcrop belt were investigated in detail for facies and stratigraphy, and sampled for carbon isotope- and trace element geochemistry, biostratigraphy, and magneto-stratigraphy (Figure 1). Samples include plugs ( $2.5 \mathrm{~cm}$ diameter, $10 \mathrm{~cm}$ length) and hand specimens, and were collected at a spacing of $16-95 \mathrm{~cm}$ ( 1 sample/59 $\mathrm{cm}$ on average) from three relatively thick (ca. $50-250 \mathrm{~m}$ ), middle- and upper-slope sections (Table 1) in the southeastern part of the Oscar Range (SO; $17^{\circ} 54.983^{\prime} \mathrm{S}, 125^{\circ} 17.9^{\prime} \mathrm{E}$ ), from the Virgin Hills formation in the Horse Spring Range (VHS; $\left.18^{\circ} 12.133^{\prime} \mathrm{S}, 126^{\circ} 01.483^{\prime} \mathrm{E}\right)$, and north of Windjana Gorge (WV; $\left.17^{\circ} 23.767^{\prime} \mathrm{S}, 124^{\circ} 56.767^{\prime} \mathrm{E}\right)$ in the Napier Range. 
For comparison purposes, samples from one relatively condensed transect through siltdominated lower-slope deposits at Casey Falls in the Lawford Range (CL; $18^{\circ} 43.983^{\prime} \mathrm{S}$, $126^{\circ} 5.119^{\prime} \mathrm{E}$ ) were also obtained. Specimens for geochemical and isotopic analysis were typically taken from $>5 \mathrm{~cm}$ below the modern surface (i.e., deepest portion of plug sample). Sampling of breccias excluded blocks and allochems, instead targeting the matrix and marine cements, to ensure that geochemical analyses were representative of the time of deposition and that paleomagnetic analyses were conducted on presumably unrotated material.

Integrated magnetostratigraphy and conodont biostratigraphy provided the primary temporal constraints for the geochemical analyses. The paleomagnetic reversal records were derived from previously published datasets analyzed at the University of Western Australia; data for VHS and SO were reported by Hansma et al. (2015) and WV was evaluated by Tohver et al. (in prep.). Paleomagnetic data for $\mathrm{CL}$ were not incorporated into this study--due to the relatively condensed nature of this section, magnetostratigraphic correlations were ambiguous. Samples obtained for conodont analysis were collected from all sections but were only age diagnostic for the SO, VHS, and CL sections (Hansma et al., 2015; Roelofs et al., 2015). For additional constraint, an independent conodont study (Klapper, 2007) conducted at the VHS site was incorporated into our work.

For carbon isotopes, 350 samples were analyzed at the Stable Isotope Research Facility at the University of Washington; 82 are presented from the SO section, 169 from VHS, 66 from WV, and 33 from CL. Hillbun et al. (in revision) evaluated all samples for diagenetic alteration and showed that bulk-rock analyses record primary marine $\delta^{13} \mathrm{C}$ values useful for regional and 
global correlations. Samples that were previously identified as potentially dolomitized, recrystallized, or otherwise altered were not included in this study. Following the bulk-rock methodology of Stephens and Sumner (2003), and the quality control workflow of Hillbun et al. (in revision), sample cores were polished and then drilled using a hand-held Woodtek drill with a diamond coated bit. All sample powders were reacted with phosphoric acid at $70^{\circ} \mathrm{C}$ in an automated Kiel device with the resulting $\mathrm{CO}_{2}$ gas analyzed by a ThermoFinnigan MAT253 mass spectrometer. The analytical precision of $\delta^{13} C_{\text {carb }}$ and $\delta^{18} \mathrm{O}$ analyses based on sample replicates and laboratory standards is $\leq \pm 0.1 \%$. Data were corrected using laboratory standards and are reported here in standard delta notation relative to VPDB.

Trace element analyses for the SO section were carried out by Chemostrat, Inc. Each sample was ground to a powder in a ball mill, and following Li-metaborate fusion, was analyzed using inductively coupled plasma optical emission spectrometry and mass spectrometry (ICP-OES MS). The methods of fusion and analysis are those described in Jarvis and Jarvis, (1995). These analytical methods result in data for both major- and trace elements, reported as oxide percent by weight and parts per million by weight (ppm), respectively. Precision for the major element data was generally better than $2 \%$ and ca. $3 \%$ for the high-abundance trace element data derived by ICP-OES. The remaining trace elements determined from the ICP-MS were generally less precise, with analytical error of ca. $5 \%$. Analytical error is $\pm 1 \%$ for major and $\pm 3-7 \mathrm{ppm}$ for trace elements depending on abundance. Expanded uncertainty values (95\% confidence) that incorporate all likely errors within a statistical framework derived from 11 batches of 5 certified reference materials (CRMs), each prepared in duplicate, are typically 5-7\% (relative) for major elements and 7-12\% (relative) for trace elements. 


\section{RESULTS}

\section{Bio- and Magnetostratigraphic Constraints on the F-F Boundary}

To determine the location of the F-F boundary, the widely used standard conodont zonations of the Frasnian (Montagne Noire succession, Klapper, 1989; Girard et al., 2005) and Famennian (Ziegler and Sandberg, 1990) are applicable to our sections in the Lennard Shelf (Figure 2). As defined at the boundary-stratotype section in Montagne Noire, France (House et al., 2000), the lower boundary of the triangularis Zone, and base of the Famennian Stage, is marked by the lowest occurrence of Palmatolepis subperlobata. In our VHS section the interval between the Lower triangularis Zone and the uppermost part of Frasnian Zone 13 (i.e. the margin of error around the stratigraphic position of the F-F) is only $20 \mathrm{~cm}$; in the SO section it is less than $4.3 \mathrm{~m}$, and in $\mathrm{CL}$ it is no more than $5.7 \mathrm{~m}$. At VHS and SO, the F-F boundary is arbitrarily placed at the stratigraphic midpoint between the latest known Frasnian (35.75 m and $228.7 \mathrm{~m}$, respectively) and earliest known Famennian (35.95 m and $233 \mathrm{~m}$, respectively) strata (Figure 2). At CL, the boundary is less biostratigraphically constrained but is currently placed just below the lowest observed occurrence of P. subperlobata, at the base of the first microbial boundstone (at 7.5 $\mathrm{m})$.

Magnetostratigraphic correlation of WV with previously examined records from VHS and SO (Hansma et al., 2015) revealed seven major magnetozones for the interval of time studied (Figure 2; Frasnian conodont Zone 11 to Famennian crepida Zone). Four periods of mixed, dominantly reversed polarity and three periods of normal polarity have been recognized, and the F-F boundary has been identified within the N7 normal chron. In the WV section, where 
biostratigraphic control is lacking, the boundary is constrained within the N7 chron, an interval that is $10 \mathrm{~m}$ thick; the F-F boundary is arbitrarily placed at the center point of this chron (Figure 2).

\section{Carbon Isotope Stratigraphy}

High-resolution carbon isotope stratigraphy reveals two major positive excursions stratigraphically lower than the F-F boundary. The timing and amplitude of these perturbations are comparable between sections, despite differences in facies, depositional environments, and paleogeographic settings (Table 1). Furthermore, petrographic analysis of selected samples reveals excellent preservation of original fabrics, relatively minor amounts of calcite recrystallization, and the absence of dolomitization, suggesting that the isotopic composition of the original seawater is represented (Hillbun et al., in revision).

Excursion 1 (Figure 3) is stratigraphically lower than excursion 2 and is observed in only two sections. In SO, an increase in $\delta^{13} \mathrm{C}$ values from $+1 \%$ o to $+4.4 \%$ (max value) is measured from megabreccia deposits and constrained within conodont Zones 10 and 13. In the VHS section, isotope values recorded in thick grainstone beds increase from $+1.2 \%$ o to $+4.7 \%$ (max value) within Zones 12 and 13a. While excursion 1 exhibits similar amplitudes and maximum values in both sections, the interval of elevated values in SO is noticeably expanded stratigraphically down-section relative to VHS. Based on conodont biostratigraphy, excursion 1 can be correlated with the deposition of the Lower Kellwasser Horizon in Europe (e.g. Buggisch and Joachimski 2006), and we interpret it to be time-equivalent to the Lower Kellwasser excursion 
reported from localities around the world (Joachimski et al., 2002; Xu et al., 2003; Stephens and Sumner, 2003; George et al., 2014; and others).

Excursion 2 is documented in all four localities (Figure 3). In both SO and VHS, $\delta^{13} \mathrm{C}$ values increase from $+1.4 \%$ and $+1.3 \%$ (baseline values) to $+3.9 \%$ and $+4.6 \%$ (max. values), respectively, within conodont Zone $13 \mathrm{~b}$. Isotopic data from WV show a positive shift ( +0.9\%o baseline values to $+3.4 \%$ max values) occurring wholly within the $R 8$ chron, which is constrained within conodont Zone 13b, and possibly 13a, based on magnetostratigraphic correlation. Although resolution of conodont biostratigraphic control is less precise in the condensed $\mathrm{CL}$ section, the data are similar; $\delta^{13} \mathrm{C}$ values from silt-dominated, lower slope facies begin to increase in Zone $13 \mathrm{~b}$ (and possibly the very uppermost part of Zone $13 \mathrm{a}$ ) from $+0.7 \%$ (baseline values), and reach maximum values $(+3.5 \%$ ) just below the first appearance of $P a$. subperlobata.

In all sections, increasing $\delta^{13} \mathrm{C}$ values associated with excursion 2 can be roughly correlated with the onset of deposition of the Upper Kellwasser horizon in Europe during Zone 13b (Figure 3). However, maximum isotope values associated with the Lennard Shelf excursion begin to decline towards more baseline values during the upper Frasnian, before the F-F boundary and the cessation of Upper Kellwasser shale deposits in Europe. In VHS, SO, and WV in particular, the F-F is clearly not associated with a positive shift in $\delta^{13} \mathrm{C}$ values. The transition from the uppermost Frasnian into the triangularis Zone of the lower Famennian is marked by slightly elevated $\delta^{13} \mathrm{C}$ values relative to Frasnian baseline values of +1 to $+1.5 \%$. This slow recovery trend, albeit typically observed only in the triangularis Zone, is characteristic of European 
isotope records (e.g. Buggisch and Joachimski, 2006). Given the temporal constraints provided by the bio- and magnetostratigraphy data, we interpret excursion 2 as the Upper Kellwasser excursion, but, it pre-dates conventional timing. Rather than maximum $\delta^{13} \mathrm{C}$ values being coincident with or closely adjacent to the F-F boundary, they occur distinctly lower, in upper Frasnian strata.

\section{Trace Elements as Tests for Anoxia and Productivity}

Based on the work of previous studies (e.g. Adams and Weaver, 1958; Jones and Manning, 1994; Algeo and Maynard, 2004; Rimmer, 2004) trace element ratios of U/Th and V/Cr are used to evaluate the state of marine oxygen levels. Because uranium and vanadium are commonly concentrated in sediments deposited under reducing conditions (Shaw et al., 1990; Emerson and Huested, 1991), comparing them with non-redox sensitive elements that are typically found in the detrital fraction ( $\mathrm{Th}$ and $\mathrm{Cr}$ ) can provide insight into changes in paleo-oxygenation. Typical range estimates for oxic, dysoxic, and anoxic water conditions have been suggested for $\mathrm{U} / \mathrm{Th}$ and $\mathrm{V} / \mathrm{Cr}$ ratios (Jones and Manning, 1994) and are employed here for reference. Given these threshold values, both paleo-redox proxies indicate low-oxygen levels (Figure 4) which correspond to the $\delta^{13} \mathrm{C}$ excursions associated with both Kellwasser events noted in this study (Figure 3). For the Upper Kellwasser in particular, it appears that $\mathrm{V} / \mathrm{Cr}$ values remain elevated for a longer period of time relative to $\mathrm{U} / \mathrm{Th}$.

Elemental ratios of $\mathrm{Cu} / \mathrm{Al}$ and $\mathrm{Ni} / \mathrm{Al}$ are reported for their use as reliable indicators of changes in paleo-bioproductivity (e.g. Piper and Perkins, 2004; Riquier et al., 2006; Perkins et al., 2008), particularly in the absence of preserved organic-rich material. While a variety of trace elements 
behave as micronutrients in oxic marine environments and are deposited in association with the organic carbon flux from surface primary productivity, both nickel and copper may be retained within their host sediments even if the organics are partially or completely remineralized after deposition (Tribovillard et al., 2006). In our study, the measured ratios of $\mathrm{Cu} / \mathrm{Al}$ and $\mathrm{Ni} / \mathrm{Al}$ exhibit less obvious trends than the ratios of $\mathrm{U} / \mathrm{Th}$ and $\mathrm{V} / \mathrm{Cr}$; there is considerable scatter associated with the Lower Kellwasser interval in both proxies, but the elevated values are correlative with the isotopic excursion. For the Upper Kellwasser, relative enrichments in $\mathrm{Ni} / \mathrm{Al}$ and $\mathrm{Cu} / \mathrm{Al}$ are observed near and above maximum $\delta^{13} \mathrm{C}$ values, respectively.

\section{DISCUSSION}

\section{Discrepancy in Timing}

The interval of time surrounding the Frasnian-Famennian (F-F) boundary is generally marked by two positive carbon-isotope excursions ( $3 \%$ average amplitude) in the marine carbonate record that correspond to the well-studied, organic-rich Kellwasser horizons and associated extinction events first described from sections in Central Europe and Morocco (McGhee et al., 1986; Buggisch, 1991; Joachimski and Buggisch, 1993; Joachimski et al., 1994; Joachimski et al., 2002). Despite the lack of similarly aged organic-rich deposits in the Lennard Shelf system, we report a European-like trend in carbon isotope values from four different measured sections.

While the absence of black shales and bituminous limestones from this time interval in Western Australia has created some doubt over the global nature of the two Kellwasser events, our geochemical results are consistent with the hypothesis that the Kellwasser events are indeed 
world-wide phenomena, and the trace element data support a period of at least dysoxia (if not anoxia) associated with the events. Our evidence for a $\delta^{13} \mathrm{C}$ excursion associated with the Lower Kellwasser event within Zones 12 and 13a is consistent across datasets in this study and corroborates the record from other sections in Australia (Stephens and Sumner, 2003; George et al., 2014) and Europe (e.g. Buggisch and Joachimski, 2006). However, our chronostratigraphically constrained record of the Upper Kellwasser excursion, particularly the timing of maximum $\delta^{13} \mathrm{C}$ values, suggests that the geochemical event is distinct from and predates the F-F boundary, in contrast with other workers' findings (Figure 5).

There are four possible ways to reconcile our data with the global data set. First, the data may reflect local phenomena or paleoenvironmental conditions unique to the Lennard Shelf and thus have no global implications. Second, a discrepancy in timing could be due either to a diachronous appearance of upper Frasnian conodont faunas or to differences in biostratigraphic resolution, possibly related to variable sampling densities. Third, these Lennard Shelf sections may represent a rarely preserved, expanded interval of the F-F transition that is not present elsewhere possibly because of highly condensed facies assemblages or unrecognized depositional hiatuses. Lastly, differences in paleogeography and ocean circulation between different study areas may account for the variation in the timing of isotopic excursions, reflecting differences in riverine input or restricted circulation in intracratonic basins, for example.

The first hypothesis, that of highly localized $\delta^{13} \mathrm{C}$ patterns, is at odds with the broad and replicable patterns in $\delta^{13} \mathrm{C}$ values recognized from the Lennard Shelf, in this study and others 
(Joachimski et al., 2002; Stephens and Sumner, 2003; George et al., 2014), which are similar in shape and amplitude to the well-studied excursions associated with the Kellwassers and equivalent horizons documented throughout Europe (e.g. Buggisch and Joachimski, 2006), North Africa (Joachimski et al., 2002), North America (e.g. Wang et al., 1996), and China (Xu et al., 2003). The refined timing of the Upper Kellwasser excursion is consistent between multiple sections of our study, regardless of differing slope facies and paleogeographic settings. Sections in Kowala, Poland and Bou Ounebdou, Morocco (Joachimski et al., 2002) also reported similar findings of elevated $\delta^{13} \mathrm{C}$ values below the F-F boundary. However, these authors argued that the expected stratigraphic continuations of the excursions were muted by recrystallization during the anaerobic oxidation of organic matter. The lack of correlative organic-rich sediments in our Lennard Shelf sections precludes this as a possible explanation for our results.

In addition to studies in the Canning Basin, the occurrence of positive excursions without accompanying anoxic sediments has been documented at the Wolayer Glatcher site in Austria (Joachimski and Buggisch, 1993) and in Nevada, USA (Joachimski et al., 2002). These authors' assessment that the anomalies in $\delta^{13} \mathrm{C}$ reflect global changes in the total dissolved marine carbon reservoir, as opposed to local anoxia, is corroborated by our findings from Western Australia. A similar argument has been made for the isotopic data associated with the Oceanic Anoxic Events in the Cretaceous Period; that is, the deposition of black shales and sub-oxic conditions were regional but their effects on the marine $\delta^{13} \mathrm{C}$ record were global (e.g. Tsikos et al., 2004; Wagreich, 2009). We therefore conclude that the Lennard Shelf isotope record is a viable marine proxy that documents the extensive burial of organic carbon in other sedimentary basins around the world (North America, Europe, China, and North Africa). 
The second hypothesis invoking the diachronous appearance of conodonts is considered unlikely. Extensive work in the Canning Basin has established that the Lennard Shelf conodont succession is comparable and time equivalent to the standard conodont zonations used globally for the upper Frasnian and lower Famennian with no discrepancies between first and last appearance data of key species (Glenister and Klapper, 1966; Druce, 1976; Ziegler and Sandberg, 1990; Klapper et al., 1993; Klapper, 1989, 2007). Bioturbation was also ruled out as a possible explanation for the observed discrepancy because the isotope excursion believed to represent the Upper Kellwasser event was found to occur as much as 20 meters or more below the F-F boundary (SO), a depth too great to reasonably account for any biological displacement of material.

In terms of sampling density and resolution, our study has very good constraints around the F-F boundary, and where we lack conodont control, magnetostratigraphy aids our correlations. However, isotopic studies commonly differ, sometimes significantly, in their biostratigraphic resolution. In the Canning Basin, for example, conodont samples were collected at a density of $>1$ sample per meter from the VHS section in the Horse Spring Range (this study; Klapper, 2007), allowing for the distinction of individual Montagne Noire conodont zones, including each subdivision of Zone 13 ( $a, b$, and $c)$. In contrast, zonal resolution for the isotopic record at Dingo Gap (George et al., 1997, cited in Stephens and Sumner, 2003) was not achieved; the low sample-density average ( 1 sample each ca. 5 meters) created an apparent compression of the isotopic excursions (Figure 6). This problem of low resolution is exacerbated by the tendency for authors to cite prior work in place of providing the actual biostratigraphic data (e.g. Wang et 
al., 1996; Joachimski et al., 2002; Xu et al., 2003; Stephens and Sumner, 2003), rendering chronostratigraphic comparisons at the zonal level difficult to assess.

This problem of uneven sampling density is especially true for the Lennard Shelf where isotopic profiles for the Late Frasnian and Early Famennian appear to differ slightly from one another in the timing of their excursions (Figure 6). For example, a recent study of a basinal core near our VHS section reported a large positive excursion, interpreted to represent the Upper Kellwasser, as occurring entirely above the F-F boundary in the triangularis Zone (George et al., 2014). The authors also documented another two $\delta^{13} \mathrm{C}$ anomalies just below the boundary, constrained by a limited number of samples, two samples over 20 meters spanning Frasnian conodont Zones 6 to 13 and three samples from conodont Zone 13. The constraints for these two lower excursions suggest a correlation with our reported excursions, and thus represent the Lower and Upper Kellwasser events, respectively. None of our studied sections record the Famennian excursion reported by George et al. (2014).

The other prominent C-isotope study of the F-F interval in the Canning Basin (Stephens and Sumner, 2003) also showed two positive isotope excursions at Dingo Gap; one occurring below the boundary and the other straddling it (Figure 6). George et al. (2014) interpreted the broad upper excursion, which had two distinct peaks, as representing both Kellwasser events. However, the conodont resolution for Dingo Gap is not sufficiently detailed to determine with any certainty the zones in which the excursions actually occur. At this time it remains unclear if differences in biostratigraphic resolution within the Canning Basin, and potentially elsewhere, can account for the observed discrepancy in timing. 
The third and fourth scenarios presented are the most plausible as they are most consistent with- and easily explained by our results. In three of our measured sections the isotopic expression of the Upper Kellwasser was observed in continuous succession in grainstone, breccia, and massive boundstone from middle- and upper-slope settings where depositional dips were relatively steep (up to $30^{\circ}$ ) and sedimentation rates presumably greater (Playton, 2008; Hansma et al., 2015). A combination of expanded stratigraphy and high-density sampling demonstrates that the timing of maximum values associated with the Upper Kellwasser excursion is different than previously documented (Figures 2 and 3). Our results from the distalslope sediments ( $\mathrm{CL}$ section) differ from the other three in that the section is highly condensed (conodont Zone $13 \mathrm{~b}$ to crepida Zone is $<10 \mathrm{~m}$ thick) and exhibits maximum $\delta^{13} \mathrm{C}$ values at or near the F-F boundary, typifying the problems created by condensed sections. We attribute these differences primarily to low sedimentation rates. While the presence of an end-Frasnian depositional hiatus or unconformity may also render isotopic records incomplete, there is no definitive evidence for this in our section. In the case of the South Oscar Range section studied by Stephens and Sumner (2003), a positive $\delta^{13} \mathrm{C}$ excursion with maximum values below the F-F boundary was observed in platform-top settings, but its potential extent remains unknown due to a documented unconformity. In any case, the isotopic pattern observed at $\mathrm{CL}$ is more comparable to those reported from sections in Europe and Morocco (Figure 5), possibly because the isotopic data associated with the Upper Kellwasser event in these regions are commonly derived from similarly condensed facies or incomplete sections.

In contrast to results from most geochemical studies during the Late Devonian, the low oxygen conditions recorded by the trace element data at SO do not appear to persist up to the F-F 
boundary; like the $\delta^{13} \mathrm{C}$ data, they occur entirely within Frasnian conodont Zone 13b (Figure 4).

This finding is comparable to findings from the Great Basin in North America where anoxic conditions also pre-dated the F-F (Bratton et al., 1999). Evidence from the fossil record suggests that the most severe pulse of the Late Devonian mass extinction likewise occurred before the boundary (McGhee, 1996); many groups became extinct before the end of the Frasnian (brachiopods, Dutro, 1981) at the base of the Upper Kellwasser horizon including trilobites (e.g. Feist, 1991), goniatites (Becker and House, 1994), ostracods (Casier, 1987; Olempska, 2002), and rugose corals (Ma and Bai, 2002). In the Canning Basin there also was a dramatic loss of conodont biodiversity at the end of conodont Zone 13b (Klapper, 2009) and a regional extinction of all ammonoid genera at the onset of 13c (Becker and House, 2009). Assuming that the global carbon pool indicates a return to less stressful conditions after the Upper Kellwasser and associated extinction events, but prior to the F-F boundary, the geological record from settings with more restricted water circulation would have experienced a lag in the recovery of $\delta^{13} \mathrm{C}$ values to baseline values. Effectively, this lag would persist until early Famennian times due to the sequestration of some localities from the global marine carbon reservoir. On a basin scale, however, the lag in isotopic values would be contemporaneous and thus $\delta^{13} \mathrm{C}$ trends would remain useful, at least as a regional correlation tool.

The paleogeography of the Late Devonian (Figure 5) indicates varying potential for isolation of some regions from the marine carbon reservoir. For example, almost all European, North American, and North African sections were located in shallow, epicontinental settings at this time. Ongoing convergence between Laurussia and Gondwana forced the closing of the Rheic Ocean and constricted the southwestern part of the Paleotethys seaway (Keppie and Ramos, 
1999; Stampfli et al., 2002; Torsvik et al., 2012). Shallow water settings in the affected regions became increasingly susceptible to the effects of the end-Frasnian regression, and also experienced an increased influx of continentally-derived material from weathering and erosion associated with active orogenies (e.g. Dalziel et al., 1994). Logically, carbonate sedimentation and reef development in these regions would have been heavily influenced by local sources of dissolved inorganic carbon (DIC) and the development of low oxygen conditions in such relatively restricted settings. Comparatively, the Canning Basin had fewer external controls; the Lennard Shelf carbonate system experienced open circulation with sea water during the Late Devonian (Carpenter et al., 1991), and there were no active mountain building events in Western Australia during that time span (Plumb, 1979; Forman and Wales, 1981). Consequently, it's unlikely that our observed discrepancy in timing of the Upper Kellwasser was a product of regional scale variations in the DIC pool. Moreover, carbonate deposition, as it pertains to reef growth, may have been more prolific in the Canning Basin because periods of more stressful paleoenvironmental conditions were likely shorter lived.

\section{Possible Excursion Mechanisms}

The black shales and bituminous limestones characteristic of the Kellwasser horizons in Europe are commonly interpreted to have been deposited under reducing oceanic conditions during intervals of substantial carbon burial (Wilde and Berry, 1984; Joachimski and Buggisch, 1993; Becker and House, 1994; Wignall, 1994; Algeo et al., 1995). The geochemical results from this Lennard Shelf study are consistent with such a scenario. The pattern of trace elements in the SO section does not support persistent or pervasive anoxia, but the $\mathrm{U} / \mathrm{Th}$ and $\mathrm{V} / \mathrm{Cr}$ patterns do indicate stressed, reducing oceanic conditions concurrent with both excursions. The record of 
low oxygen conditions is clearer for the Upper Kellwasser interval with the more diffuse pattern from the Lower Kellwasser suggesting more intermittent periods of oxygen restriction. While middle-slope settings may reflect water oxygenation by deep currents, the megabrecciadominated slope facies from which the Lower Kellwasser was analyzed likely indicate reefal collapse and re-deposition of platform-derived material, which may reflect more oxic conditions, within an overall anoxic environment (lower) on the slope.

Reduced oxygen levels in the SO section may be related to the prevalence of bottom-water anoxia in the deepest parts of the global ocean (e.g. Goodfellow et al., 1989). Decades of research have shown that the Frasnian stage is coincident with a globally warm climate, the proliferation of land plants, and eustatic sea-level rise punctuated by transgressive-regressive cycles--conditions that are favorable to episodic ocean stratification and the formation of anoxia in deep-water settings (Brass et al., 1982; Johnson et al., 1985; Wilde and Berry, 1986; Tyson and Pearson, 1991; Algeo et al., 1995; Hallam and Wignall, 1999; Averbuch et al., 2005). Short-term transgressive pulses have been shown to correlate with the two Kellwasser excursions in both Europe (Johnson et al., 1996; Buggisch and Joachimski, 2006) and the Canning Basin (Stephens and Sumner, 2003). These transgressive episodes would result in a landward migration of oxygen-depleted waters from bathyal settings into shallower environments such as the Lennard Shelf System.

These findings that support anoxia contradict the conclusions of George et al. (2014), who described the positive excursions in the Lennard Shelf as occurring in "oxic facies." These authors hypothesized that the $\delta^{13} \mathrm{C}$ anomalies could be attributed to an increase in biological 
productivity due to enhanced nutrient influxes from continental weathering during times of lowered relative sea level. While our geochemical results support a relative increase in marine productivity during the Upper Kellwasser interval, and perhaps to a lesser extent for the Lower Kellwasser, it seems unlikely that (regional) enhanced land-derived nutrient loading was the driving factor. Relatively distal sections, such as those on the lower slope and in the basin (i.e., section VHS of this study; George et al., 2014) are not typically affected by terrestrial influx; productivity blooms are commonly restricted to near-shore environments where the influence of continentally derived material is greatest (Riquier et al., 2006). The lack of active orogenies in Western Australia at this time further decreases the likelihood of extensive nutrient transport. A more probable explanation for the observed trace element pattern, at least for the Upper Kellwasser, is that localized phosphorous renewal under deep-water anoxic conditions led to eutrophication (Ingall and Jahnke, 1997), resulting in the expansion of oxygen-deprived water into shallower depositional settings. This hypothesis was similarly suggested for the Upper Kellwasser in the Harz Mountains of Germany by Riquier et al. (2006).

In the event that terrestrially sourced productivity was the primary driver of paleoenvironmental change and isotopic excursions recorded in the Lennard Shelf System, we would expect to see some vestige of the organic byproducts, particularly in sections (SO, WV) that have high sedimentations rates conducive to the preservation of organic matter (e.g. Muller and Suess, 1979; Sageman and Lyons, 2003) and which represent relatively proximal settings compared to the basinal core studied by George et al. (2014). However, no such organic-rich material was detected. The wholesale decomposition of organic material is unlikely, given that all isotopic profiles documented from the Lennard Shelf display no evidence 
of a ${ }^{12} \mathrm{C}$ influx from organic carbon remineralization (this study; Joachimski et al. 2002; Stephens and Sumner 2003; George et al. 2014).

\section{CONCLUSION}

This work presents an integrated view from the northern margin of Gondwana, constraining the pattern of carbon-isotope perturbations across the Frasnian-Famennian transition at the intrazonal scale. The Lennard Shelf isotope record has been interpreted as a viable marine proxy that reflects global oceanic conditions and the burial of organic carbon in sedimentary basins elsewhere. Minor differences in the chemostratigraphic profiles notwithstanding, studies of the Canning Basin indicate depleted $\delta^{13} \mathrm{C}$ values at or below the F-F boundary (Figure 6). We propose that the relative depletion reflects a sudden decline in primary productivity at the end of the Frasnian, much like negative excursions observed at other mass extinction boundaries (e.g. Zachos et al., 1989; Holser, 1997; Galli et al., 2005; Stanley, 2010).

Despite the absence of lithological evidence for the well-known Kellwasser events, two positive $\delta^{13} \mathrm{C}$ excursions have been identified from four Lennard shelf outcrops that are comparable in amplitude to Late Devonian sections around the world. Well-constrained biostratigraphy and magnetostratigraphy in the three stratigraphically expanded sections helped to constrain the Upper Kellwasser carbon isotope excursion (maximum values) to MN Zone 13b and thus differentiate it in time from the F-F boundary. These results suggest that major environmental and biotic stressors on the global marine carbon pool leading up to a mass extinction may have diminished before the F-F boundary itself. As a result, isotopic records with prolonged excursions into the Famennian may be experiencing a lag effect due to isolation of the DIC pool 
in more restricted, shallow-marine basins. These results demonstrate that isotopic data alone are insufficient to determine the position of a major mass extinction boundary in geological time. However, integrated datasets, such as the one presented in this study, demonstrate that $\delta^{13} \mathrm{C}$ excursions, at least within a basin, can be used as chronostratigraphic markers and thus have utility for correlation.

Geochemical data for the Upper Kellwasser interval are most consistent with the interpretation that a globally warm climate and eustatic highs during the Late Devonian led to the formation of bottom-water anoxia in deep ocean basins that periodically spread into shallower settings on the Lennard Shelf via transgressive pulses and/or the development of eutrophic conditions due to phosphorous regeneration. These conditions are arguably widespread, but the Lennard Shelf is unique in that it records the global signal (geochemically) without accompanying lithological evidence (i.e. black shales). A similar scenario for the Lower Kellwasser is postulated although the role of eutrophication remains to be determined; as such, further trace element analyses are needed.

\section{ACKNOWLEDGMENTS}

We are grateful to the Australian Research Council (grant LP0883812), MERIWA (grant M396), WAERA, CSIRO, Arc Energy, Chevron, NAl, and the ESS Department at the University of Washington; without their generous support this work would not have been possible. A special thanks to Ray Addenbrooke, Kliti Grice, Jerone Hansma, Mitch Harris, Trevor Holland, Joe Kirschvink, Sergei Pisarevsky, Shane Schoepfer, and Tom Tobin for their assistance in the field and/or input during discussions. Additional thanks to the Geological Survey of Western 
Australia and Wundargoodie Aboriginal Safaris for their logistical support during field work. We would also like to acknowledge the UW IsoLab for their help with the many isotope analyses.

\section{REFERENCES}

Adams J. A. S. and Weaver C. E. (1958) Thorium-to-uranium ratios as indicators of sedimentary processes: Example of concept of geochemical facies. AAPG Bull. 42, 387-430.

Algeo T. J., Berner R. A., Maynard J. B. and Scheckler S. E. (1995) Late Devonian Oceanic Anoxic Events and Biotic Crises: "Rooted" in the Evolution of Vascular Land Plants? GSA Today $5,45,64-66$.

Algeo T. J. and Maynard J. B. (2004) Trace-element behavior and redox facies in core shales of Upper Pennsylvanian Kansas-type cyclothems. Chem. Geol. 206, 289-318.

Averbuch O., Tribovillard N., Devleeschouwer X., Riquier L., Mistiaen B. and van Vliet-Lanoe B. (2005) Orogenic-induced continental weathering and organic carbon burial as major causes for climatic cooling at the Frasnian-Famennian boundary (ca 376 Ma BP). Terra Nova 17, 25-34.

Becker R. T. and House M. R. (2009) Devonian ammonoid biostratigraphy of the Canning Basin. In Devonian Reef Complexes of the Canning Basin, Western Australia, Geological Survey of Western Australia Bulletin. pp. 415-431.

Becker R. T. and House M. R. (1994) Kellwasser events and goniatite successions in the Devonian of the Montagne Noire with comments on possible causations. Cour. Forschungsinstitut Senckenberg 169, 45-77.

Becker R. T. and House M. R. (1997) Sea level changes in the Upper Devonian of the Canning Basin, Western Australia. Cour. Forschungsinstitut Senckenberg 199, 129-146.

Blakey R. (2008) Gondwana paleogeography from assembly to breakup-A 500 my odyssey. Geol. Soc. Am. Spec. Pap. 441, 1-28.

Bond D., Wignall P. B. and Racki G. (2004) Extent and duration of marine anoxia during the Frasnian-Famennian (Late Devonian) Mass Extinction in Poland, Germany, Austria and France. Geol. Mag. 141, 173-193.

Brass G. W., Southam J. R. and Peterson W. H. (1982) Warm saline bottom water in the ancient ocean. Nature 296, 620-623.

Bratton J. F., Berry W. B. N. and Morrow J. R. (1999) Anoxia pre-dates Frasnian-Famennian boundary mass extinction horizon in the Great Basin, USA. Palaeogeogr. Palaeoclimatol. Palaeoecol. 154, 275-292. 
Buggisch W. (1991) The global Frasnian-Famennian »Kellwasser Event». Geol. Rundsch. 80, 4972.

Buggisch W. and Joachimski M. (2006) Carbon isotope stratigraphy of the Devonian of Central and Southern Europe. Palaeogeogr. Palaeoclimatol. Palaeoecol. 240, 68-88.

Carpenter S. J., Lohmann K. C., Holden P., Walter L. M., Huston T. J. and Halliday A. N. (1991) $\delta 180$ values, and $\mathrm{Sr} / \mathrm{Mg}$ ratios of Late Devonian abiotic marine calcite: Implications for the composition of ancient seawater. Geochim. Cosmochim. Acta 55.

Casier J. G. (1987) Etude biostratigraphique et pal'eo'ecologique des ostracodes du r'ecif de marbre rouge du Hautmont `a Vodel'ee (partie sup'erieure du Frasnien, Bassin de Dinant, Belgique). Rev. Pal'eobiologie 6, 193-204.

Dalziel I. W. D., Dalla Salda L. H. and Gahagan L. M. (1994) Paleozoic Laurentia-Gondwana interaction and the origin of the Appalachian-Andean mountain system. Geol. Soc. Am. Bull. 106, 243-252.

Druce E. C. (1976) Conodont biostratigraphy of the Upper Devonian reef complexes of the Canning Basin, Western Australia. Bulletin of the Bureau of Mineral Resources, Geology, and Geophysics 158, 303 p.

Emerson S. R. and Huested S. S. (1991) Ocean anoxia and the concentrations of molybdenum and vanadium in seawater. Mar. Chem. 34, 177-196.

Feist R. (1985) Devonian Stratigraphy of the Southeastern Montagne Noire (France). Cour. Forschungsinstitut Senckenberg 75, 331-352.

Feist R. (1991) The Late Devonian trilobite crisis. Hist. Biol. 5, 197-214.

Forman D. J. and Wales D. W. (1981) Geological evolution of the Canning Basin, Western Australia. Bur. Miner. Resour. Aust. Bull. 210, 91.

Galli M. T., Jadoul F., Bernasconi S. M. and Weissert H. (2005) Anomalies in global carbon cycling and extinction at the Triassic/Jurassic boundary: evidence from a marine Cisotope record. Palaeogeogr. Palaeoclimatol. Palaeoecol. 216, 203-214.

Van Geldern R., Joachimski M. M., Day J., Jansen U., Alvarez F., Yolkin E. A. and Ma X. P. (2006) Carbon, oxygen and strontium isotope records of Devonian brachiopod shell calcite. Palaeogeogr. Palaeoclimatol. Palaeoecol. 240, 47-67.

Geldsetzer H. H. J., Goodfellow W. D. and McLaren D. J. (1993) The Frasnian-Famennian extinction event in a stable cratonic shelf setting: Trout River, Northwest Territories, Canada. Palaeogeogr. Palaeoclimatol. Palaeoecol. 104, 81-95. 
Geldsetzer H. H. J., Goodfellow W. D., McLaren D. J. and Orchard M. J. (1987) Sulfur-isotope anomaly associated with the Frasnian-Famennian extinction, Medicine Lake, Alberta, Canada. Geology 15, 393-396.

George A. D., Chow N. and Trinajstic K. M. (2014) Oxic facies and the Late Devonian mass extinction, Canning Basin, Australia. Geology 42, 327-330.

George A. D., Playford P. E., Powell C. M. and Tornatora P. M. (1997) Lithofacies and sequence development on an Upper Devonian mixed carbonate-siliciclastic fore-reef slope, Canning Basin, Western Australia. Sedimentology 44, 843-867.

Girard C., Klapper G. and Feist R. (2005) Subdivision of the terminal Frasnian linguiformis conodont Zone, revision of the correlative interval of Montagne Noire Zone 13, and discussion of stratigraphically significant associated trilobites. In Understanding Late Devonian and Permian-Triassic Biotic and Climatic Events: Towards an Integrated Approach (eds. J. D. Over, J. R. Morrow, and P. B. Wignall). Developments in Palaeontology and Stratigraphy. Elsevier. pp. 181-198.

Glenister B. F. and Klapper G. (1966) Upper Devonian conodonts from the Canning Basin, Western Australia. J. Paleontol. 40, 777-842.

Goodfellow W. D., Geldsetzer H. H. J., McLaren D. J., Orchard M. J. and Klapper G. (1989) Geochemical and isotopic anomalies associated with the Frasnian-Famennian extinction. Hist. Biol. 2, 51-72.

Goodfellow W. D., Geldsetzer H. H. J., McLaren D. J., Orchard M. J. and Klapper G. (1988) The Frasnian-Famennian Extinction: Current Results and Possible Causes. , 9-21.

Guppy D. J., Lindner A. W., Rattigan J. H. and Casey J. N. (1958) The geology of the Fitzroy Basin, Western Australia. Aust. Bur. Miner. Resour. Bull. 36, 116.

Hallam A. and Wignall P. B. (1999) Mass extinctions and sea-level changes. Earth Sci. Rev. 48, 217-250.

Hansma J., Tohver E., Yan M., Trinajstic K., Roelofs B., Peek S., Slotznick S., Kirschvink J., Playton T. E., Haines P. and Hocking R. M. (2015) Late Devonian carbonate magnetostratigraphy from the Oscar and Horse Spring Ranges, Lennard Shelf, Canning Basin, Western Australia. Earth Planet. Sci. Lett. 409, 232-242.

Hillbun K., Katz D., Playton T. E., Trinajstic K., Machel H. G., Haines P., Hocking R. M., Roelfs B., Montgomery P. and Ward P. (in revision) Global and local controls on carbon isotope fractionation in Upper Devonian carbonates from the Lennard Shelf, Western Australia: a streamlined approach for generating primary marine secular curves for regional correlation. AAPG Bull. 
Holser W. (1997) Geochemical events documented in inorganic carbon isotopes. Palaeogeogr. Palaeoclimatol. Palaeoecol. 132, 173-182.

House M. R., Becker R. T., Feist R., Flajs G., Girard C. and Klapper G. (2000) The Frasnian/Famennian boundary GSSP at Coumiac, southern France. Cour. Forschungsinstitut Senckenberg 225, 59-75.

Ingall E. and Jahnke R. (1997) Influence of water-column anoxia on the elemental fractionation of carbon and phosphorus during diagenesis. Mar. Geol. 139, 219-229.

Jarvis I. and Jarvis K. E. (1995) Plasma spectrometry in earth sciences: techniques, applications and future trends. Chem. Geol. 95, 1-33.

Joachimski M., Buggisch W. and Anders T. (1994) Mikrofazies, Conodontenstratigraphie und Isotopengeochemie des Frasne/Famenne-Grenzprofils Wolayer Gletscher (Karnische Alpen). Jb Geol B -A 50, 183-195.

Joachimski M. M. and Buggisch W. (1993) Anoxic events in the late Frasnian--causes of the Frasnian-Famennian faunal crisis? Geology 21, 675-678.

Joachimski M. M., Pancost R. D., Freeman K. H., Ostertag-Henning C. and Buggisch W. (2002) Carbon isotope geochemistry of the Frasnian-Famennian transition. Palaeogeogr. Palaeoclimatol. Palaeoecol. 181, 91-109.

Johnson J. G., Klapper G. and Elrick M. (1996) Devonian Transgressive-Regressive Cycles and Biostratigraphy, Northern Antelope Range, Nevada: Establishment of Reference Horizons for Global Cycles. Palaios 11, 3-14.

Johnson J. G., Klapper G. and Sandberg C. A. (1985) Devonian eustatic fluctuations in Euramerica. Geol. Soc. Am. Bull. 96, 567-587.

Jones B. and Manning D. A. C. (1994) Comparison of geochemical indices used for the interpretation of paleoredox conditions in ancient mudstone. Chem. Geol. 111, 111129.

Kennard J. M., Jackson M. J., Romine K. K., Shaw R. D. and Southgate P. N. (1994) Depositional sequences and associated petroleum systems of the Canning Basin, WA. In The Sedimentary Basins of Western Australia (eds. P. G. Purcell and R. R. Purcell). Proceedings of Petroleum Exploration Society of Australia Symposium, Perth, WA. pp. 657-676.

Keppie J. D. and Ramos V. A. (1999) Odyssey of terranes in the lapetus and Rheic oceans during the Paleozoic. In Laurentia-Gondwana Connections before Pangea (eds. V. A. Ramos and J. D. Keppie). Geological Society of America Special Papers, Boulder, Colorado. pp. 267276. 
Klapper G. (2007) Frasnian (Upper Devonian) conodont succession at Horse Spring and correlative sections, Canning Basin, Western Australia. J. Paleontol. 81, 513-537.

Klapper G. (1989) The Montagne Noire Frasnian (Upper Devonian) conodont succession. Devonian World 3, 449-468.

Klapper G. (2009) Upper Devonian conodonts in the Canning Basin. In Devonian Reef Complexes of the Canning Basin, Western Australia Geological Survey of Western Australia Bulletin. pp. 405-414.

Klapper G., Feist R., Becker R. T. and House M. R. (1993) Definition of the Frasnian/Famennian Stage boundary. Episodes 16, 433-441.

Ma X. P. and Bai S. L. (2002) Biological, depositional, microspherule, and geochemical records of the Frasnian/Famennian boundary beds, South China. Palaeogeogr. Palaeoclimatol. Palaeoecol. 181, 325-346.

McGhee G. R. (1996) The Late Devonian mass extinction : the Frasnian/Famennian crisis, Columbia University Press, New York.

McGhee G. R., Orth C. J., Quintana L. R., Gilmore J. S. and Olsen E. J. (1986) Late Devonian "Kellwasser Event" mass-extinction horizon in Germany: No geochemical evidence for a large-body impact. Geology 14, 776-779.

Muchez P., Boulvain F., Dreesen R. and Hou H. F. (1996) Sequence stratigraphy of the FrasnianFamennian transitional strata; a comparison between South China and southern Belgium. Palaeogeogr. Palaeoclimatol. Palaeoecol. 123.

Muller P. J. and Suess E. (1979) Producivity, sedimentation rate, and sedimentary organic matter in the oceans - I. Organic carbon preservation. Deep-Sea Res 26, 1347-1362.

Nothdurft L. D., Webb G. E. and Kamber B. S. (2004) Rare earth element geochemistry of Late Devonian reefal carbonates, Canning Basin, Western Australia: confirmation of a seawater REE proxy in ancient limestones. Geochim. Cosmochim. Acta 68, 263-283.

Olempska E. (2002) The Late Devonian Upper Kellwasser Event and entomozoacean ostracods in the Holy Cross Mountains, Poland. Acta Palaeontol. Pol. 47, 247-266.

Perkins R. B., Piper D. Z. and Mason C. E. (2008) Trace-element budgets in the Ohio/Sunbury shales of Kentucky: Constraints on ocean circulation and primary productivity in the Devonian-Mississippian Appalachian Basin. Palaeogeogr. Palaeoclimatol. Palaeoecol. 265, 14-29.

Piper D. Z. and Perkins R. B. (2004) A modem vs. Permian black shale - the hydrography, primary productivity, and water-column chemistry of deposition. Chem. Geol. 206, 177-197. 
Playford P. E. (1980) Devonian "great barrier reef" of Canning Basin, Western Australia. AAPG Bull. 64, 814-840.

Playford P. E., Hocking R. M. and Cockbain A. E. (2009) Devonian Reef Complexes of the Canning Basin, Western Australia, Geological Survey of Western Australia, Bulletin 145.

Playford P. E. and Lowry D. C. (1966) Devonian reef complexes of the Canning Basin, Western Australia. Geol. Surv. West. Aust. Bull. 118, 150.

Playton T. E. (2008) Characterization, variations, and controls of reef-rimmed carbonate foreslopes. Unpublished, The University of Texas at Austin.

Plumb K. A. (1979) The tectonic evolution of Australia. Earth-Sci. Rev. 14, 205-249.

Rimmer S. M. (2004) Geochemical paleoredox indicators in Devonian-Mississippian black shales, Central Appalachian Basin (USA). Chem. Geol. 206, 373-391.

Riquier L., Tribovillard N., Averbuch O., Devleeschouwer X. and Riboulleau A. (2006) The Late Frasnian Kellwasser horizons of the Harz Mountains (Germany): Two oxygen-deficient periods resulting from different mechanisms. Chem. Geol. 233, 137-155.

Roelofs B., Playton T., Barham M. and Trinajstic K. (2015) Upper Devonian microvertebrates from the Canning Basin, Western Australia. Acta Palaeontol. Pol. 65.

Sageman B. B. and Lyons T. W. (2003) Geochemistry of fine-grained sediments and sedimentary rocks. Treatise Geochem. 7, 115-158.

Sandberg C. A., Morrow J. R. and Ziegler W. (2002) Late Devonian sea-level changes, catastrophic events, and mass extinctions. Spec. Pap.- Geol. Soc. Am., 473-488.

Sandberg C. A., Poole F. G. and Johnson J. G. (1988) Upper Devonian of Western United States, 183-220.

Sepkoski J. J. (1986) Global bioevents and the question of periodicity. In Global bio-events (ed. O. Walliser). Springer-Verlag, Berlin. pp. 47-61.

Shaw T. J., Geiskes J. M. and Jahnke R. (1990) Early diagenesis in differing depositional environments: the response of transition metals in pore water. Geochim. Cosmochim. Acta 54, 1233-1246.

Stampfli G. M., von Raumer J. F. and Borel G. D. (2002) Paleozoic evolution of pre-Variscan terranes: From Gondwana to the Variscan collision. In Variscan-Appalachian dynamics: The building of the late Paleozoic basement (eds. J. R. Martinez Catalan, R. D. Hatcher Jr., R. Arenas, and F. Diaz Garcia). Geological Society of America Special Papers, Boulder, Colorado. pp. 263-280. 
Stanley S. M. (2010) Relation of Phanerozoic stable isotope excursions to climate, bacterial metabolism, and major extinctions. PNAS 107, 19185-19189.

Stephens N. P. and Sumner D. Y. (2003) Late Devonian carbon isotope stratigraphy and sea level fluctuations, Canning Basin, Western Australia. Palaeogeogr. Palaeoclimatol. Palaeoecol. 191, 203-219.

Torsvik T. H., Van Der Voo R., Preeden U., Mac Niocaill C., Steinberger B., Doubrovine P. V., van Hinsbergen D. J. J., Domeier M., Gaina C., Tohver E., Meert J. G., McCausland P. J. A. and Cocks L. R. M. (2012) Phanerozoic polar wander, paleogeography and dynamics. Earth Sci. Rev. 114, 325-368.

Tribovillard N., Algeo T. J., Lyons T. W. and Riboulleau A. (2006) Trace metals as paleoredox and paleoproductivity proxies: An update. Chem. Geol. 232, 12-32.

Tsikos H., Jenkyns H. C., Walsworth-Bell B., Petrizzo M. R., Forster A., Kolonic S., Erba E., Premoli-Silva E., Baas M., Wagner T. and Sinninghe-Damste J. S. (2004) Carbon-isotope stratigraphy recorded by the Cenomanian-Turonian Oceanic Anoxic Event: correlation and implications based on three key localities. J. Geolological Soc. Lond. 161, 711-719.

Tyson R. V. and Pearson T. H. (1991) Modern and ancient continental shelf anoxia: an overview. Geol. Soc. Lond. 58, 1-24.

Veevers J. J. and Wells A. T. (1961) The Geology of the Canning Basin, Western Australia., Bureau of Mineral Resources, Geology and Geophysics.

Wagreich M. (2009) Coniacian-Santonian oceanic red beds and their link to Oceanic Anoxic Event 3. In Cretaceous Oceanic Red Beds: Stratigraphy, Composition, Origins, and Paleoceanographic and Paleoclimatic Significance (eds. X. Hu, C. Wang, R. W. Scott, M. Wagreich, and L. Jansa). SEPM Special Publication. pp. 235-242.

Wang K., Geldsetzer H. H. J., Goodfellow W. D. and Krouse H. R. (1996) Carbon and sulfur isotope anomalies across the Frasnian-Famennian extinction boundary, Alberta, Canada. Geology 24, 187-191.

Wang K., Orth C. J., Attrep M., Chatterton B. D. E., Hou H. and Geldsetzer H. H. J. (1991) Geochemical evidence for a catastrophic biotic event at the Frasnian/Famennian boundary in south China. Geology 19, 776-779.

Wendt J. and Belka Z. (1991) Age and depositional environment of Upper Devonian (early Frasnian to early Famennian) black shales and limestones (Kellwasser Facies) in the eastern Anti-Atlas, Morocco. Facies 25, 51-90.

Wignall P. B. (1994) Black shales. Oxford University Press, New York. 
Wilde P. and Berry W. (1986) The role of oceanographic factors in the generation of global bioevents. In Global Bio-Events (ed. O. Walliser). Lecture Notes in Earth Sciences. Springer Berlin/Heidelberg. pp. 75-91.

Wilde P. and Berry W. B. N. (1984) Destabilization of the Oceanic Density Structure and its significance to marine "Extinction" events. Palaeogeogr. Palaeoclimatol. Palaeoecol. 48, 143-162.

Xu B., Gu Z., Liu Q., Wang C. and Li Z. (2003) Carbon isotopic record from Upper Devonian carbonates at Dongcun in Guilin, southern China, supporting the world-wide pattern of carbon isotope excursions during Frasnian-Famennian transition. Chin. Sci. Bull. 48, 1259.

Zachos J. C., Arthur M. A. and Dean W. E. (1989) Geochemical Evidence for Suppression of Pelagic Marine Productivity at the Cretaceous/Tertiary Boundary. Nature 337, 61-64.

Ziegler W. and Sandberg C. A. (1990) The Late Devonian standard conodont zonation. Cour. Forschungsinstitut Senckenberg 121, 115.

\section{FIGURE AND TABLE CAPTIONS}

Figure 1: Map of field area (modified after Playford et. al., 2009). Samples for this study were collected from four outcrops along the Lennard Shelf in Western Australia; Casey Falls (CL), Virgin Hills Formation at Horse Spring Range (VHS), South Oscar Range (SO), and the Windjana Gorge area (WV). Insets show the location of the Lennard Shelf carbonate system in relation to the Canning Basin and Australia.

Figure 2: Measured sections showing bio- and magneto-stratigraphic control used for correlation and to constrain the position of the F-F boundary. Paleomagnetic reversal records (partials) are from Hansma et al., (2015) and Tohver et al., (in prep). Grey shading shows correlation of normal (and mixed-normal) polarity chrons. $\mathrm{M}=$ mudstone, $\mathrm{W}=$ wackestone, $\mathrm{P}=$ packstone, $\mathrm{G}=$ grainstone, $\mathrm{R}=$ rudstone, $\mathrm{Br}=\mathrm{breccia}, \mathrm{B}=$ bound/bafflestone. 
Figure 3: Comparison of isotopic profiles across the F-F boundary in the Lennard Shelf carbonate system. Grey highlighting of maximum $\delta^{13} \mathrm{C}$ values shows the stratigraphic positions of excursions (Ex.) 1 and 2 relative to the standard (Ziegler and Sandberg, 1990) and Montagne Noire (Klapper, 1989) conodont zonations. Position of the F-F boundary is constrained by bioand magneto-stratigraphic data (see Figure 2 for magnetostratigraphic correlation). Inset shows isotopic profiles to-scale; dashed lines show biostratigraphic correlations and the solid line $=$ the Frasnian-Famennian (F-F) boundary.

Figure 4: Chemostratigraphic profiles of elemental ratios used as qualitative proxies for paleoredox conditions and bioproductivity. Shaded areas represent the stratigraphic position of maximum carbon isotope values associated with the Lower and Upper Kellwasser excursions (Ex. 1 and 2, respectively; Ex. = excursion). Trace element ratio thresholds for oxic, dysoxic, and anoxic water conditions from Jones and Manning (1994).

Figure 5: A. Comparison of $\delta^{13} \mathrm{C}$ maxima for the Upper- and Lower Kellwasser geochemical events from Guilin, China (Xu et al., 2003), Devils Gate, Nevada (Joachimski et al., 2002), Wolayer Glacier, Austria (Buggisch and Joachimski, 2006), Benner Quarry, Germany (Joachimski and Buggisch, 1993), Kowala, Poland (Joachimski et al., 2002), the Lennard Shelf, Western Australia (this study), and Bou Ounebdou, Morocco (Joachimski et al., 2002). The depositional environment for each section has been indicated and biostratigraphic constraints drawn in accordance with the original data. B. Paleo reconstruction of the Late Devonian (Blakey, 2008) showing locations of the various $\delta^{13} \mathrm{C}$ records. C. Generalized lithologic- and isotopic trends 
across the F-F boundary for sections in Laurussia and Eastern Gondwana (modified from Joachimski and Buggisch, 1993).

Figure 6: Comparison of carbon isotope profiles, and relative timing of $\delta^{13} \mathrm{C}$ excursions (maximum values), from various studies in the Lennard Shelf carbonate system (Stephens and Sumner, 2003; George et al., 2014; this study).

Table 1: Depositional characteristics and isotopic data associated with Kellwasser equivalent excursions 1 and 2. Amplitude and maximum $\delta^{13} \mathrm{C}$ values are reported relative to VPDB. Data for excursion 1 at $W V$ and $C L$ are not available because neither section extended into the age appropriate strata. See Figure 1 for non-abbreviated locality names. 
Figure 1

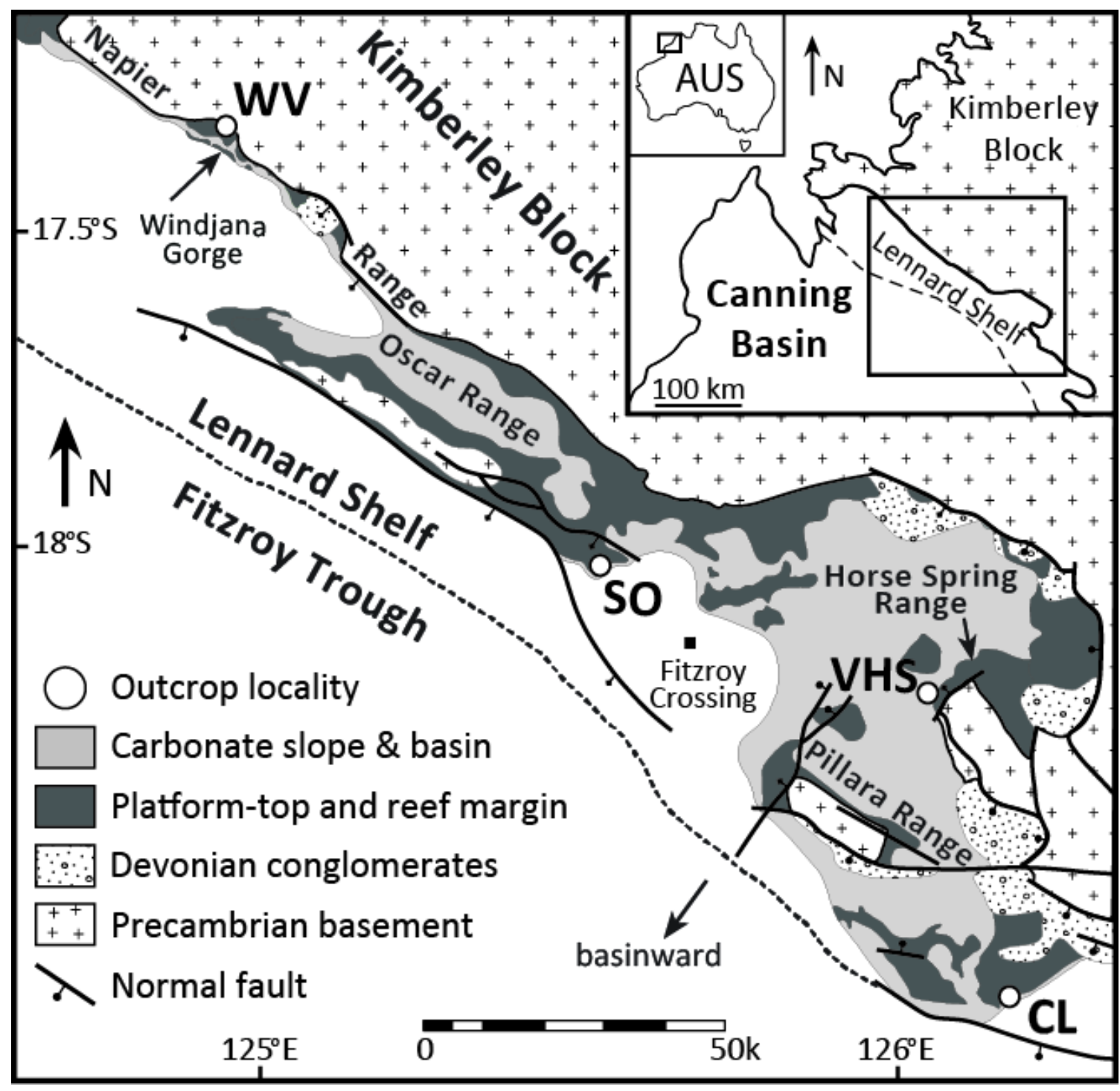


Figure 2

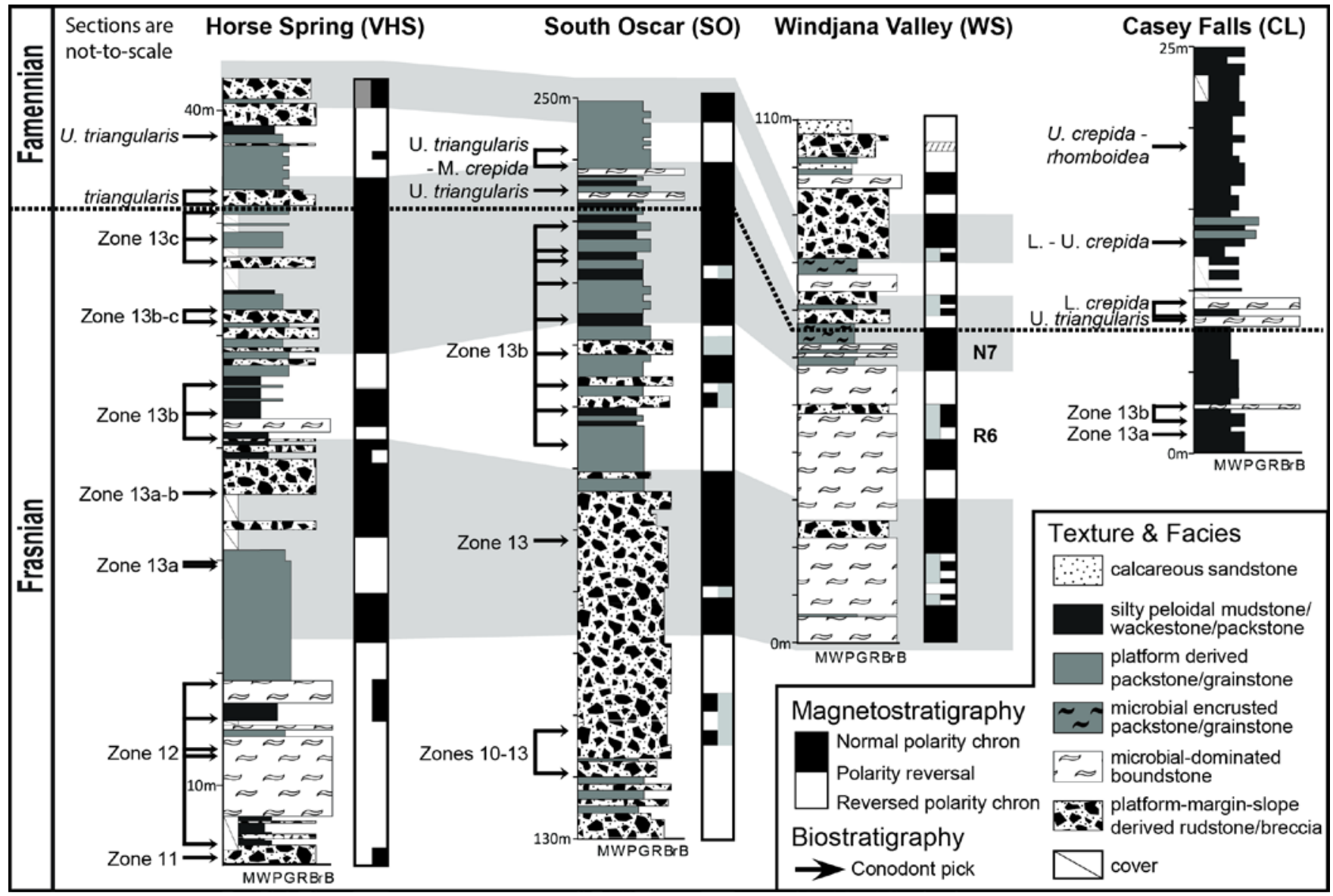


Figure 3

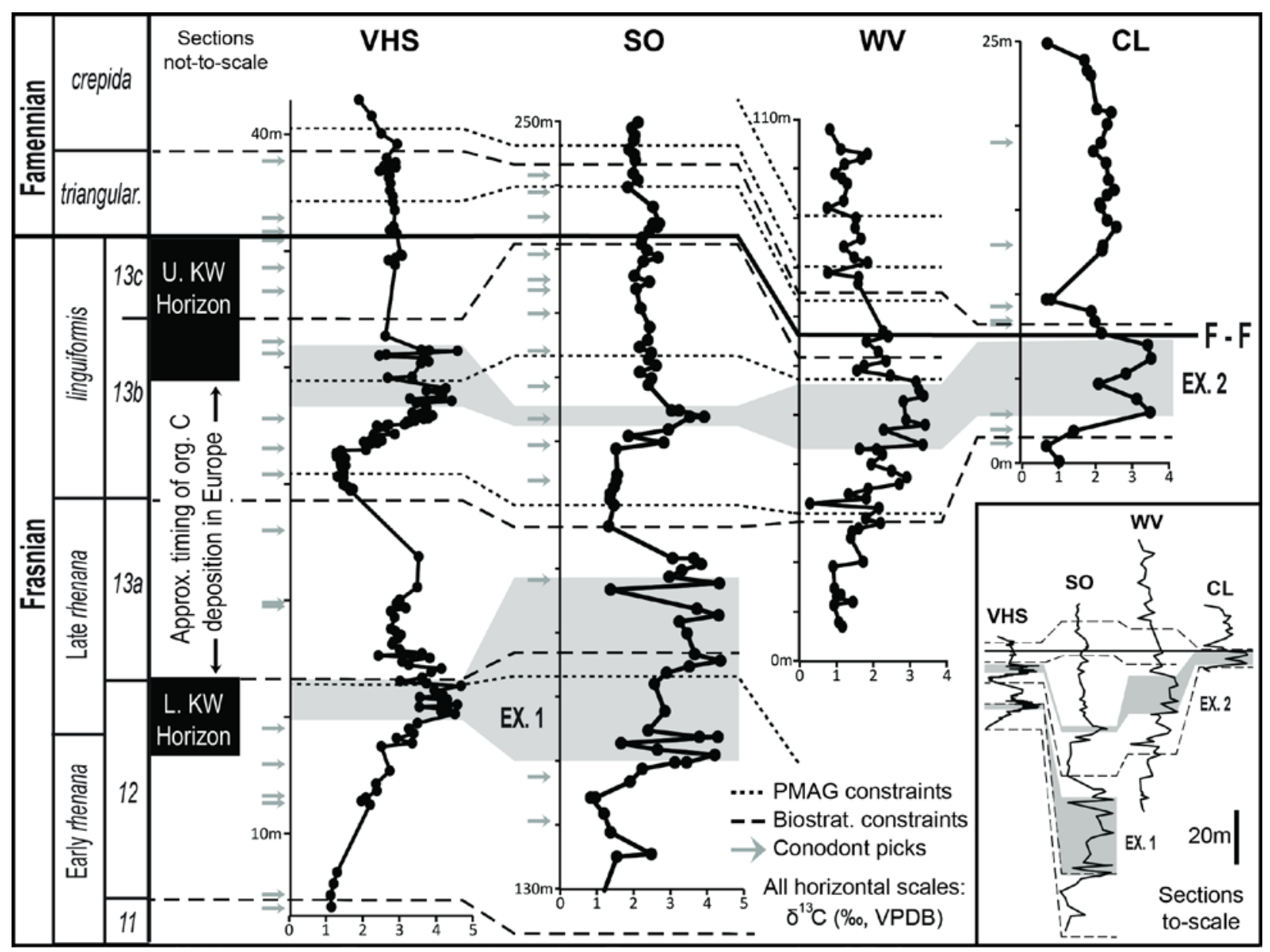


Figure 4

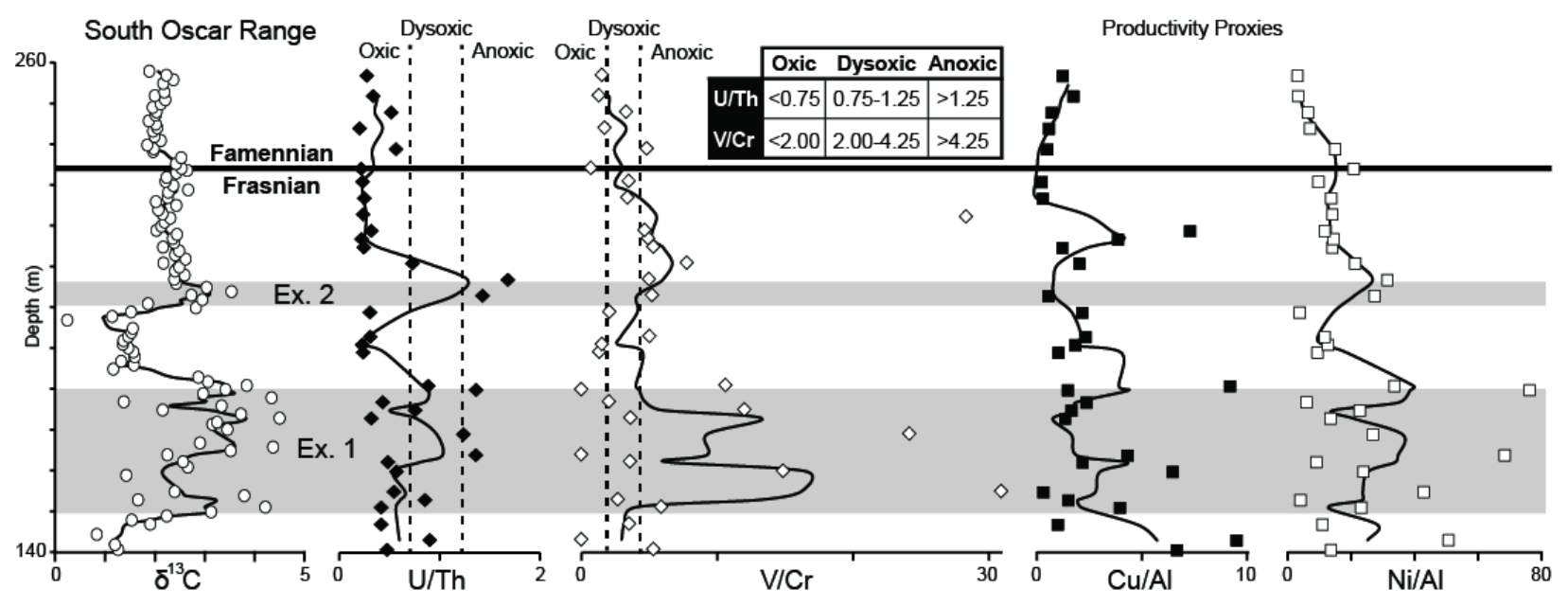

Figure 5

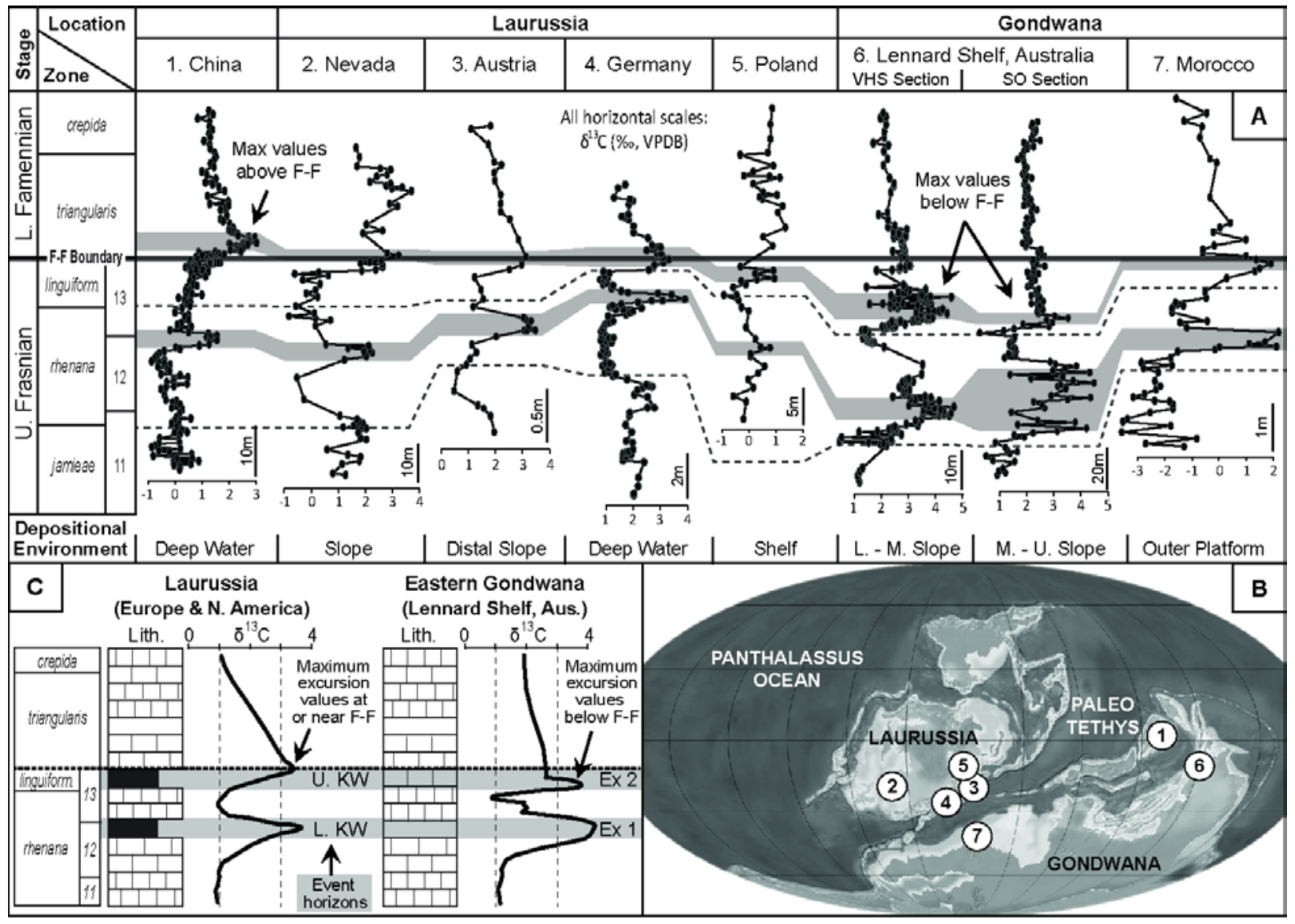


Figure 6

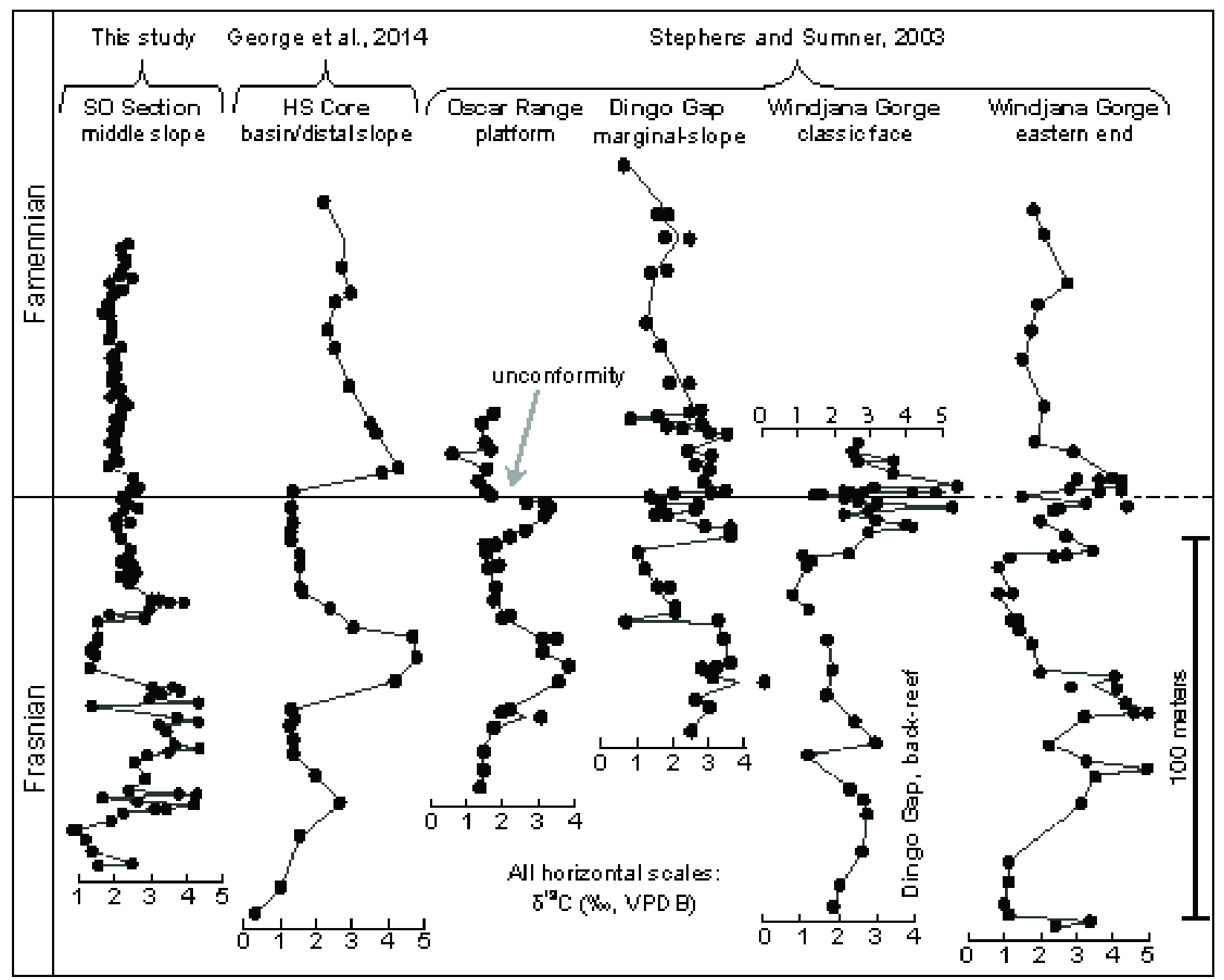


Table 1

\begin{tabular}{|c|c|c|c|c|c|c|c|c|}
\hline \multirow{2}{*}{ Section } & \multirow{2}{*}{$\begin{array}{c}\text { Paleogeographic } \\
\text { Setting }\end{array}$} & \multirow{2}{*}{$\begin{array}{l}\text { Depositional } \\
\text { Environment }\end{array}$} & \multicolumn{3}{|c|}{ Excursion 1 (L.KW equivalent) } & \multicolumn{3}{|c|}{ Excursion 2 (U.KW equivalent) } \\
\hline & & & Associated Facies & Amp. & Max. & Associated Facies & Amp. & Max. \\
\hline so & $\begin{array}{l}\text { isolated, open } \\
\text { marine }\end{array}$ & $\begin{array}{c}\text { middle - } \\
\text { upper slope }\end{array}$ & $\begin{array}{l}\text { skeletal-rich } \\
\text { megabreccia }\end{array}$ & $+3.4 \%$ & $+4.4 \%$ & $\begin{array}{c}\text { platform-derived } \\
\text { packstone/grainstone, } \\
\text { breccia }\end{array}$ & $+2.5 \%$ & $+3.9 \%$ \\
\hline VHS & $\begin{array}{l}\text { land attached, } \\
\text { broad } \\
\text { embayment }\end{array}$ & middle slope & $\begin{array}{l}\text { skeletal-peloidal } \\
\text { packstone/ } \\
\text { grainstone, } \\
\text { microbial-dominated } \\
\text { boundstone }\end{array}$ & $+3.5 \%$ & $+4.7 \%$ & $\begin{array}{l}\text { platform-derived } \\
\text { grainstone, } \\
\text { megabreccia, } \\
\text { wackestone }\end{array}$ & $+3.2 \%$ & $+4.6 \%$ \\
\hline wV & land attached & upper slope & \multicolumn{3}{|c|}{ Not Available } & $\begin{array}{l}\text { massively bedded } \\
\text { microbial boundstone, } \\
\text { megabreccia }\end{array}$ & $+2.5 \%$ & $+3.4 \%$ o \\
\hline $\mathrm{CL}$ & $\begin{array}{l}\text { land attached, } \\
\text { reef spine }\end{array}$ & lower slope & \multicolumn{3}{|c|}{ Not Available } & $\begin{array}{c}\text { silt-dominated } \\
\text { wackestone/packstone }\end{array}$ & $+2.8 \%$ & $+3.5 \%$ \\
\hline
\end{tabular}

